\title{
Adopting Cell Phones in EFL Teaching and Learning
}

\author{
Guoqiang Cui \\ Shuyan Wang \\ The University of Southern Mississippi
}

\begin{abstract}
Though Mobile Learning (ML) has a brief history of no more than four decades, the medium is developing rapidly with the upgrading of different mobile devices. Among all the devices, cell phones have great potential in language teaching and learning. This article explores the different devices especially cell phone use in ML. The paper also reviews teaching and learning of English as a Foreign Language (EFL) in China and discusses potential applications of cell phones in Chinese EFL teaching and learning.
\end{abstract}

Keywords: Cell Phone, EFL, Teaching and Learning

\section{Introduction}

The advent of Mobile Learning (ML) came with the invention of portable technologies and mobile devices in the 1970s and 1980s. Mobile devices have also undergone great changes and revolutions in the past few decades with the rapid development of modern science and technology. Mobile devices such as cell phones, personal digital assistants (PDAs), smart phones, etc., are carrying powerful functions as do personal computers. Because these devices are small, smart, portable, and comfortable to utilize, particularly to the digital natives, all these devices are regarded as teaching instruments in the ML.

Among all the mobile devices, cell phones are probably the most popular and widely used all over the world, especially in China. China is now the world's largest wireless market and has the greatest number of cell phone users. According to China's
Ministry of Information Industry (MII), China had 539.4 million handset users, with an increase of 78.32 million in the first eleven months of 2007. Users sent 535.08 billion SMS messages in the same period, for an increase of 37.5 percent from the year-ago period (Qu, 2007).

The number of cell phone users in China is impressive because of the advanced functions offered by cell phones such as text messaging, wireless Internet, MP3 players, global positioning system (GPS), etc. However, most people use cell phones as a communication or recreational tool opposed for learning and studying.

According to a survey that was conducted by M: Metrics, a research firm that monitors cell phone media use, "about 35 percent of Chinese cell phone owners reported that they listened to music on their cell phones every month, compared with 20 percent in Spain, 18.9 percent in Britain, and 5.7 percent in 
the United States" (Leske, 2008, ๆ 2). Over 30 percent of the people in Italy, Spain and Britain "use their phones to send or receive photos and videos, and only half as many do so in China". "Users in the United States lead the poll in email usage with 11.6 percent, compared with 9 percent in Spain and Britain, and only 2.5 percent in China" (Lamb, 2008, ๆ 4 \& 5).

Compared with other countries, Chinese users did not adequately explore functions of cell phones and this leads to a great waste of mobile resources. Powerful features and functions of mobile devices offer cell phone users such as teachers and instructional designers great potential and feasibility for educational use, especially in the mobile learning, which will give people from diverse fields a new way to learn. Nonetheless, Chinese users have yet seen the educational potential of cell phones.

Mobile Learning has immensely developed in the United States (US), United Kingdom (UK), and other European countries while ML is still at its starting point in China. Allowing for China's great cell phone market and the medium's potential interactive uses, this paper will discuss possible future applications of cell phones in China's EFL (English as a Foreign Language) learning following a brief review of current popular mobile device usage and an analysis of the Chinese present EFL learning situation.

\section{An Overview of Mobile Devices Applied in $\mathrm{ML}$}

In the transient history of mobile learning, people performing in the technical platform have been exploring various devices they could use to best facilitate the effects of mobile learning. Nowadays, the digital natives are taking great advantage of development of the latest, up-to-date devices. People can learn whenever and wherever they want to. Additionally, mobile devices provide individuals with abundant and quality information and materials for many benefits such as mobile learning, E-learning, etc.

This section will mainly discuss the development and the usage of the major, latest, and wide-use mobile devices in mobile learning: handheld computers, audio and video players, and cell phones.

\subsection{Handheld Computers}

As its literal meaning, handheld computers are portable computers which are small and can be held in one's hand. At present, products like PDAs (Personal Digital Assistants) and smart phones are so advanced and versatile there is hardly any distinction between them. They are convenient to carry and have computer-like functions. Handheld computers can be used to calculate, browse online, send and receive E-mails, play music, typewrite, record video and audio, send fax, play games, and even make phone calls. The original handheld computers have small keyboards and screens, while the latest versions are more like PDAs using the stylus as an input device. Some of them even use voice recognition technology through voice input. The smart phones are usually mobile-phone-like and have more advanced functions than cell phones. These devices can enhance the classroom activity and expand the learning of time and space.

L\&S Learning Support Service (LSS) at the University of Wisconsin-Madison integrated wireless handheld technology for the teaching and learning of foreign languages and cultures. They received wireless handhelds from big companies and 
started three projects. One project provided pictures online and asked students to partake in discussions. Students in the second project were engaged in a chat activity. In the third project, students were asked to view poems on their handhelds and then were required to submit their assignments. The experiment turned out to provide "very popular chat sessions" and "motivating students to produce both quantity and quality in the target language" (Samuels, n.d., p. 2).

Though the above portable devices have computer-like features, they can hardly replace computers because of their limitations such as the small screen size, limited storage space, and slow processing speed that could easily frustrate learners.

\subsection{Audio and Video Players}

Audio and video players include iPod, MP3, and MP4. While walking down the street, it is a common sight to see pedestrians walking or exercising while carrying one of these players. As these players are portable and simple to use, each of them carries their unique role in ML. For instance, students can download, store, and playback instructional materials on these players whenever convenient.

The Apple Company offers ML materials for learners to download. According to the Duke University's report in 2005, they offered iPods to their first year students so that students could use iPod devices to capture course content, field notes, repeat listening, etc. The result showed that the devices brought them "convenience for both faculty and students, flexible location-independent access to digital multimedia course materials and greater student engagement and interest" (Center for Instructional Technology [CIT], 2005 , p. 2). But sometimes we have to accept the fact that players are restricted to video and audio play functions, and are not as powerful and intelligent as computers.

\subsection{Cell Phones}

Cell phones as ML devices are more prevalent and the most popular of mobile devices. Today, there are almost three billion cell phone subscribers worldwide. Cell phones are making our lives easier and becoming very hard to image life without cell phones because people are accustomed to them. Cell phones are so advanced and smart that they actually perform almost the same functions and features as personal computers as "cell phones are not just communication devices sparking new modalities of interacting between people, they are also particularly useful computers that fit your pocket, are always with you, and are always on. Like all communication and computing devices, cell phones, can be used to learn" (Prensky, 2004, p. 1).

Before teaching and learning with cell phones can be done, a thorough look and analysis of their basic and up-to-date functions is necessary:

Voice: This is the basic function of cell phones; people use voice to communicate. Every day, people all around the world spend a large amount of time talking through cell phones. But, how can people best integrate the voice function of the cell phones into education? In some new computer applications such as VoiceThread, people can use their cell phones to call and record their voices to communicate with others or post their comments to their VoiceThread page. Recently, a new type of cell phone is equipped with a voice recorder that people can record messages and then send them via Internet or Bluetooth. In UK, the CTAD Company even 
created "voice-only mobile phone learning for school dropouts with language needs" (Prensky, 2004, p. 4). Another latest free source, Snapvine, allows anyone to use their mobile phones to audioblog or record voice. Users can "post directly to a public blog on their site, or to a private 'voice comments' page" (Kolb, 2008, ๆ 1).

SMS (short message service): SMS is a service that allows people to interchange text messages between cell phones. A great number of short messages are sent every day and people usually find that sending SMS is a good alternative to communicate with other people compared with face-toface communication. They may feel more comfortable and relaxed while sending SMS because they can have more time to ponder what to write. Besides, sending SMS is much cheaper than making calls. SMS system can be used to help students learn foreign languages and teachers can use SMS to communicate with one student or even one group of students. The BBC Company once launched one program to help learning English via SMS in that "Users in the world's largest single mobile telephone market will receive a daily text message on their mobile containing an English phrase together with the Chinese translation" (British Broadcasting Company [BBC], 2003, n.p.). MMS (Multimedia Messaging Service) is also available in many places, but the cost is comparatively higher than SMS. However, sending pictures with the MMS is still one good option.

Browsing: To browse with cell phones is one very convenient way for students to surf online. They can use browsers to check e-mails, read instructional materials, such as online textbooks, and watch lectures from anywhere and at anytime. There are also many more mobile sites available to students.
Students can just log online via their cell phones and obtain access to the instructional materials. In Japan, cell-phone books have already won respect as an emerging culture. "The Tokyo-based wireless service provider offers 150 books on its site, called 'Bunko Yomihodai,' which means 'All You Can Read Paperbacks." The company "began the service in 2003 and saw user interest grow last year. There are now about 50,000 subscribers" (Kageyama, 2005, ๆ 13).

Downloading: People can download various kinds of materials they like to their cell phones easily. There are more free online material for users to download such as e-books, music, instructional materials, and the like. People can enjoy their downloaded music on their cell phones rather than having an MP3 player. Students can download their required e-books and read them whenever they have time without carrying the heavy books. People even download useful software and dictionaries.

Camera: Recently, people have argued that cell phone cameras can disturb people's lives and interrupt people's privacy. Proper use of the camera on the cell phone is of vital importance. Students will greatly benefit from having a camera on the cell phones when collecting scientific data, documenting information, and storing visual material. However, to maintain the quality of the images, a higher camera resolution is required. Therefore, large cell phone companies have produced cell phone cameras with much better resolution than those currently available. Sony Ericsson has announced a phone with a 3-megapixel digital camera, a special photo light, and an $8 \mathrm{x}$ zoom lens. Samsung will be soon be manufacturing a cell phone with a 3 GB hard drive which will open a world of new possibilities for photos. (Berger, n.d.) 
Gaming: The game feature is available in almost every cell phone, either entertaining or instructional. Games offer people a good way to relax and people can also benefit a lot from playing games such as developing problem solving and critical thinking skills. Presently, there are many instructional games available such as memorizing the spelling of words. Designers are doing research on how to design the best instructional game system so that students can best benefit from playing games. For example, a team of researchers and students at the University of California at Berkley is conducting a project called MILLEE, known as Mobile and Immersive Learning for Literacy in Emerging Economies, to develop mobile phone games aimed at teaching literacy to children in India. "The group decided to design games in order to increase the interest of children in education and students play the mobile games as part of an after-school program for two hours at a time" (Ramey, 2008, 9 4) to help improve learning.

Though cell phones have their unique features and functions as well as their great potentials in teaching and learning, we have to accept the fact that they also have some flaws. Like some other mobile devices, cell phones do not have enough screen size for people to read. The limited battery does not allow longevity of use. Cell phones usually cannot offer users as much storage space as computers and the absence of keyboard can also disenable people to type long. All of these factors cannot be overlooked and should be considered when exploring the medium's usage and potential.

\section{EFL Teaching in China}

After China enters the World Trade Organization (WTO) and especially with the 2008 Olympic Games held in Beijing, there is an ever increasing popularity in English learning in China. Griffith (n.d.) asserts that "the Chinese nation is huge and hungry for the English language" and "the past few years have seen a remarkable explosion in the number of private language institutes and companies" (Griffith, ๆ 5). In big cities like Beijing and Shanghai, people of all age groups are taking great efforts to learn English. Groups of young people also find English learning becoming more and more useful; as a result, the EFL teaching in China is really becoming a huge industry nowadays. Many private English educational organizations in China, such as New Oriental School, Crazy English, New Channel, etc. are springing up like mushrooms and they offer many English learning courses and exam trainings that cover all areas. In order to register for the course, students have to apply for it a half year earlier before the course even begins.

Compared with the great passion for learning English, many EFL teaching in China, particularly the EFL teaching at the university level is not adequate because of limited qualified teachers, classrooms, and modern technologies. Most universities, especially in the inland cities, have not used technologies fully, let alone using cell phones in EFL.

The situation of student learning is also quite worrisome. A lot of Chinese students started learning English from K-7 level; some children even started learning English in kindergarten. But after graduating from college, a great number of students still have great difficulties in listening and speaking. So, what are the causes of these problems? After years of teaching experience and research, the authors found the following problems: 
Wrong learning purpose. "In China, English is viewed as 'the gatekeeper' to higher education, employment, economic prosperity and social status" (Niu \& Wolff, n.d., p.1). Students have to perform well in various English tests in order to pass the "gate." Therefore, in some of their minds, the main purpose of learning English is to pass exams. Learners are asked to memorize all the new words or phrases, become familiar with grammatical exercises, and to make sure that they can do well in all kinds of standardized tests. Although the Chinese Educational Department calls for quality-education, various tests limit teachers to provide a truly authentic teaching environment. As a result, most students cannot communicate fluently in English even after ten-years of studying English. Reading is no longer a big problem for most of the Chinese learners, but they do have a difficult time communicating with native speakers and some of them even have trouble distinctly expressing themselves.

Low-quality materials. Some schools still use the out-of-date textbooks or materials that even native speakers find hard to understand. These kinds of materials are so tedious and not related to students' daily lives that students are not motivated to learn and even become less interested in learning. For instance, some textbooks include articles about the brain drain situation in India, AIDS, and other scientific experiments and stories. Though it is indispensable for students to read extensively, they need more interesting and fun reading materials instead of boring paper-based articles. English learning materials should include multimedia resources rather than paper-based materials only.

No English environment. Students in China usually do not speak English until they are forced to do so in class.
In most cases, teachers teach English in Chinese. For instance, long articles have to be translated into Chinese, complicated grammar has to be explained in Chinese, and even instructions have to be delivered in Chinese. In addition, English is taught in large classrooms with about 40-50 students in one class, and in some cases there are even more students. Therefore, students hardly have the opportunities to speak in class and teachers encounter problems both physically and psychologically. As Xu (2001) described, "The teachers in large classes may feel physically weary; they may unawarely speak louder and move more often or longer distances than they do in small classes etc. Psychologically, some teachers feel it intimidating to face a large 'crowd' of students, especially when they don't have much idea who their students are and what their students are expecting from them" $(\mathrm{Xu}$, 2001, ๆ 8)

In order to create a language speaking environment for students, many universities form English Corners on campuses; however, the so-called English Corner sometimes merely offers fixed topics like making introduction or talking about the weather. On the contrary, students do find this as a good place to make friends instead of learning English.

Technology issue. "The use of information technology in Chinese higher education came relatively late" and "the process of informationalization of higher education in China is suffering from a number of problems and challenges" (Cai \& Guo, 2006, p. 353 \& 359). Equipment budget at most universities are too limited to purchase advanced hardware and software, as well as upgrading existing equipment. Even if some universities receive the latest technology devices, they cannot take full advantage 
of them because they lack appropriate professional development training. Most English teachers have heavy teaching loads and hardly have any time to receive training or self-study the advanced functions. As a result, English class is most frequently delivered in the traditional classroom with little technology aids and students only have access to the language labs once every two weeks. Even if some of the English courses are conducted in the multimedia classroom, the untrained teachers cannot effectively integrate the multimedia technology into the English teaching and learning.

\section{The Promise of Cell Phone in the Future}

\subsection{A Review of Cell Phone Application in China's EFL Teaching}

China owns the world's most up-todate technology and resources. There are considerable Websites offering English learning resources like Listening Express, 51 test, Put English, etc. Some big companies like BBC also offer quality English learning materials online.

Some pioneers have already explored ways to use cell phones in EFL learning long ago, but the influence is small and some projects are abandoned half way. For example, BBC joined forces with Sina, one of China's largest and most influential Website to launch a mobile phone service for learning English. The news can still be found in the $\mathrm{BBC}$ press office online. But, the Website which used to offer mobile phone services for English learning had already been converted for music downloading and achieved little effect during that period. The small influence could be attributed to the market not being mature enough or not quite ready at that time.
Years later, E-learning Lab of Shanghai Jiao Tong University (SJTU) has successfully delivered its undergraduate-level courses through mobile devices such as cell phones and PDAs. The mobile learning system developed by the E-learning Lab supports three types of learning access: tuning into live broadcasts, Video-on-demand (VOD), and downloading archived broadcasts to mobile devices (Wang, Shen, Tong, Yang, \& Han, 2005).

In February of this year, China Mobile and China Daily, one of the largest English newspaper producers, have just launched China's first English language "mobile newspaper." The paper sends multimedia messages to subscribers twice daily and "the target users are foreign officials, embassy representatives, members of chambers of commerce and foreign companies, white collar workers, public servants and college students" (China Daily, 2008, ๆ 7).

Considering China's large cell phone market and great English learning potential, Nokia will launch English lessons for Chinese people through a mobile phone service, "With Mobiledu, anybody living in China will have easy and fast access to courses for rapid English learning" (Balan, 2007, ๆ 1).

\subsection{Suggestions on Cell Phone Use}

With the great development of cell phone technologies, services, and the realization of cell phones' instructional potential, educators are more than ready to apply cell phones in EFL learning. How can educators best take advantage of the cell phone popularity and apply them in China's EFL teaching and learning? The following are some suggested elements and steps to consider: 
4.2.1. Attitudes. The primary issue is people's attitudes toward the usage of cell phones. Schools and institutions do have their reasons to worry about cell phone usage on campus. For example, students might abuse them by browsing online or playing games while they are in class or they might even become too addicted. But, considering great advantages that cell phones can bring, the adoption of cell phones in education should be greatly encouraged, "It's time we asked the kids to get them out and use them for learning, rather than just banning them for use at school where more relevant work is required like filling out worksheet study guides based on a textbook that is five years old" (Fryer, n.d., p. 107).

Educational departments, schools and teachers should advocate and promote the integration of cell phones in educational fields. For example, proper and updated policy or guidance regarding the promotion of technology integration in education such as cell phones should be drawn up. More funds and attention should be allocated so that teachers and students can benefit more from the use of cell phones. With joint efforts, cell phones would be more welcomed and play an increasing role in education.

\subsubsection{Prepare quality multimedia materials} online. Because English learning is composed of four basic sections-listening, speaking, reading and writing - the audience needs to acquire the impact of English from all dimensions. Schools and teachers should offer students more quality multimedia materials that tailor to cell phones and the nature of foreign language learning. Students also need quality materials that would inspire more interest in English language learning.
Actually, the online teaching system does have the ability to convert the traditional face-to-face English class to the online format and this will immensely encourage students from all fields to learn English. Online English courses also offer students greater flexibility to learn and arrange their own time because "online learning allows for flexibility of access, from anywhere and usually at anytime-essentially, it allows participants to collapse time and space" (Cole, 2000, p. 1).

4.2.3. Transmission system. Cell phone transmission systems need to be upgraded to ensure the quality of calling, sending, and receiving. All the disadvantages of cell phone transmissions such as weak signals, connection costs, radiation, etc. need to be seriously treated so that users can make full use of all the features without much hindrance.

China's telecommunications is developing at a faster rate than ever before as "in the past decade, the average annual growth rate of the telecommunications sector exceeded several times the growth of China's gross domestic product (GDP)" (Wauschkuhn, 2001, p.7). Universities should take this opportunity and set up their own campus wireless cell phone call system to minimize the cost of phone calls. As thus, students can feel free to communicate with each other in English or ask questions from teachers without worrying about the cost. Students can record their oral tasks and send them back to the teacher for evaluation. To cut down the cost, universities can seek cooperation with telecommunications companies to obtain free or cheaper instructional cell phones for students. 
At the same time, schools should also take great consideration of the SMS system. They should take efforts to cut down the cost of sending text and ensure the high quality of sending and receiving. Students do not want to send text messages early in the morning only to receive the replies at night. Schools can also use SMS system to send out administrative information. They can send information such as events or reminders, so it is convenient for users to discover the information stored in their cell phones without writing notes. Students can provide feedback to teachers via SMS. Homework and some tests can also be delivered in this way.

Bandwidth issue should also be considered so that students can download all their instructional materials in a short time. With limited bandwidth, downloading can be frustrating because it might take hours to accomplish even a simple task. Telecommunications Company or schools with Intranet should update their systems so students can easily obtain their learning materials from online.

4.2.4. Teacher's training. Teachers are the key factors in integrating technology such as adopting cell phones in EFL teaching. Teachers should become familiar with all the updated technology and acquire essential skills toward applying technology in their teaching. Teachers also need to provide instructions to students on the use of technology in class. In order to ensure success, government and schools should offer training opportunities to teachers, so that they will be prepared and confident in using all of these technologies. Teachers' technology training in China is gaining more attention and "in 2001, there were about 14,000 instructors have attended all kinds of training workshops, and 2,700 of them has obtained training certificates" (Liang et al., 2005, p. 198). With more skills and confidence in applying all the technologies, teachers can better facilitate EFL teaching and learning and students can learn and benefit more.

4.2.5. Student's participation. Students need to have basic computer literacy and actively engage in using all of the technologies. They should be encouraged to acquire basic training from the computer center or from their teachers. They should also be guided toward learning all the options while using their cell phones. With adequate guidance, students can view their teacher's Web page or access some other online English learning resources via cell phones, and they can also take online tests. Schools and teachers could also design customized mobile Websites based on the unique features of the cell phones so that students will find it is easier to navigate using their cell phones.

Students could download materials or software for further reading, listening, and finishing their assignments or obtaining help in learning English after class. If teachers and students are in the same location, they can also share files via Bluetooth. Students should know how to store educational materials such as listening materials or books in their cell phones for later review. They should also be able to store reading materials such as the passages and articles from their textbooks or keep the listening materials downloaded from other places. With all the instructional multimedia materials stored in their cell phones, students can have more opportunities to work within an authentic context (Nikolova, 2002).

4.2.6. Development of cell phone and its applications. With the adoption and development of cell phone usage in EFL 
teaching and learning, companies should help students update their cell phones and programmers, technologists, and teachers should also develop suitable software or applications for teachers and students to use. Cell phones could be produced with more volume capability for students to store information and materials. Teachers and students will also expect to obtain an alternative solution for the limited screen size and the lack of a keyboard.

Programmers and game designers can produce some inspiring and meaningful cell phone games for students. Playing games is always an enjoyable experience and if a considerable number of instructional programs can be converted to games, students would demonstrate a greater interest in learning English language. Games, such as word shooting, would be especially helpful and meaningful to English learners because they can learn words while playing games.

\section{Conclusion}

With the development of technology and mobile learning, cell phones will play a more important role in education. They are powerful tools and can bear almost the same functions as personal computers. Considering China's greater number of cell phone users and the medium's interactive potential, cell phones in China can perform their unique roles, particularly in EFL teaching in China. EFL education in China is mushrooming and the integration of cell phones would present a brand new and refreshing experience to both teachers and students. They can take advantage of all the great features and capabilities of cell phones and students can learn English in an easier and more effective way. Cell phone applications can greatly ensure the success of EFL teaching and learning in China.

\section{References}

Balan, E. (2007, May). Nokia Is China's English Teacher-Nokia makes English Learning Easy and Accessible. Retrieved June 24, 2008 from http:// news.softpedia.com/news/Nokia-IsChina-039-s-English-Teacher-55883. shtml

Berger, S. (n.d.). How to Access Cell Phone Features. Retrieved April 20, 2008, from http://www.aarp.org/learntech/computers/ howto/cell_phone_features.html

BBC. (2003, February 9). BBC Uses Mobile Phones to Teach the English Language in China. Retrieved June 28, 2008 from http://www.bbc.co.uk/pressoffice/ pressreleases/stories/2003/09 september/02/chinese_mobile.shtml

Cai, Y., \& Guo, W. (2006). Responses of Chinese Higher Education to the Information Society. E-Learning, 3, 353-360.

University of Duke University, Durham, Center for Instructional Technology. (2005, June). Duke University iPod First Year Experience Final Evaluation Report. Retrieved April 20, 2008, from http://cit.duke.edu/pdf/reports/ipod_ initiative_04_05.pdf

China Daily. (2008, February 26). 1st EnglishChinese Mobile Paper Launched in China. Retrieved June 24, 2008 from http://www.chinadaily.com.cn/ china/2008-02/26/content_6486167.htm

Cole, R. A. (2000). Issues in Web-based pedagogy: A critical primer. Westport, CT: Greenwood Press.

Fryer, W. (n.d.). Scissors and Cell Phones. Retrieved April 28, 2008 from http:// www. 21 centuryconnections.com/ node $/ 262$

Griffith, S. (n.d.). Teaching English in Asia. Retrieved September 8, 2008 from http:// www.transitionsabroad.com/listings/ 
work/esl/articles/workinasia.shtml

Kageyama, Y. (2005, March 23). Reading Books on Cell Phones. CBS News. Retrieved June 23, 2008 from http:// election.cbsnews.com/stories/2005 /03/23/tech/main682569.shtml

Kolb, L. (2008). Mobile Voice with Snapvine. Message posted to http://www.cellphone sinlearning.com/2008/03/mobile-voicewith-snapvine.html

Lamb, P. (2008). How the Chinese Use Their Cell Phones. Message posted to http:// www.smartmobs.com/2008/02/17/howthe-chinese-use-their-cell-phones

Leske, N. (2008, February 11). Chinese Cell Phone Users Tune into Music. International Herald Tribune. Retrived April 28, 2008, from http://www.iht.com/articles /2008/02/11/technology/cellphone.php

Liang, G., Song, J., Liu, G., Walls, R., Li, G., Wang, Z., et al. (2005). Are teachers in China ready to teach in the 21 st century? Journal of Technology and Teacher Education, 13(2), 197209.

Nikolova, O. R. (2002). Effects of Students' Participation in Authuring of Multimedia Materials on Student Acquisition of Vocabulary. Language Learning \& Technology, 6(1), 100-122.

Niu, Q. \& Wolff, M. (n.d.). English as a Foreign Language: The Modern Day Trojan Horse? Retrieved September 9, 2008, from http://www.usingenglish. com/esl-in-china/trojan-horse.pdf

Prensky, M. (2004). What Can You Learn From A Cell Phone? - Almost Anything. Journal of Online Education, 1 (5). Retrieved April 20, 2008 from http:// www.ojc.edu/content/facultyStaff/ What $\% 20$ Can $\% 20$ You\%20Learn $\% 20$ from $\% 20$ a $\% 20 \mathrm{Ce} 11 \% 20$ Phone_\%20 Almost $\% 20$ Anything!.pdf

Qu, L. (2007, Deceber 26). MII: China Exceeds 908M Phone Users. JLM Pacific
Epoch. Retrieved May 1, 2008, from http://www.pacificepoch.com/news stories? $\mathrm{id}=\mathrm{P} 113176$

Ramey, C. (2008). MILLEE: English Literacy through Games on the Third Screen. Message posted to http:// mobileactive.org/millee-learningenglish-through-games-smallscreen

Samules, J. (n.d.). Wireless and Handheld Devices for Language Learning. Paper presented at the 19th Annual Conference on Distance Teaching and Learning. Retrieved April 20, 2008, from http:// www.uwex.edu/disted/conference/ Resource_library/proceedings/03_50. pdf

Wang, M. J., Shen, R.M., Tong, R., Yang, F. \& Han, P. (2005). Mobile learning with Cellphones and PocketPCs. In Lau, R.W. H., Li, Q., Cheung, R., \& Liu, W. Y. (Eds.), Advances in Web-Based Learning - ICWL 2005, 3583, 332-339.

Wauschkuhn, M. (2001). Telecommunication and Economic Development in China. Asian Pacific Dynamism 1550-2000, 16. Retrieved September 8, 2008, from http://www.iwim.uni-bremen.de/ publikationen/pdf/c016.pdf

$\mathrm{Xu}$, Z. (2001). Problems and strategies of teaching English in large classes in the People's Republic of China. In A. Herrmann and M. M. Kulski (Eds), Expanding Horizons in Teaching and Learning. Proceedings of the 10th Annual Teaching Learning Forum, 7-9 February 2001. Perth: Curtin University of Technology. Retrieved April 20, 2008 from http://lsn.curtin.edu.au/tlf/tlf2001/ xu.html 


\section{Contact the Authors:}

Guo Qiang Cui, M.S.

Instructonal Technology

The University of Southern Mississippi

Email: andyguoqiang@hotmail.com

Shuyan Wang, Ph.D.

Instructional Technology

The University of southern mIssissippi

Email: shuyan.wang@usm.edu 